\title{
Development of a Bacterial Fuel Cell
}

\section{Dr. Paul F. Penko P.E., Baldwin Wallace University}

Paul F. Penko, Ph.D.

Adjunct Professor, Baldwin Wallace University, Physics Department.

Previously: 2005-10: Adjunct Professor, Ohio State University, Aerospace Engineering Department. 1969-2005: Aerospace Engineer, NASA Glenn Research Center.

Society Membership: AIAA, ASME, ASEE 


\title{
Development of a Bacterial Fuel Cell
}

\author{
Nathan J. Onchuck, Alumnus \\ Alyssa A. Grygiel, Junior \\ Callie Ann Jakuszeit, Senior \\ Joseph Briski, Senior \\ Paul F. Penko, Faculty Advisor \\ Baldwin Wallace University
}

\begin{abstract}
Purpose of this project is to develop a practical, working fuel cell that utilizes naturally occurring bacteria that decomposes organic material producing hydrogen ions that combine with oxygen in air to produce electrical power. A laboratory model was built and tested for purposes of understanding how a device could be designed for practical use in a sewage-treatment plant, cesspool or manure pond and how it would have to be scaled to produce useful electrical power. The project requires knowledge in several technical and scientific areas and is conducted on a student-team basis with a faculty advisor.
\end{abstract}

\section{Introduction}

This project is multi-disciplinary as it involves biology, chemistry, physics and engineering. At least one student from each of these disciplines is a member of the project team. The team meets once a week to discuss plans for designs, fabrication of test units, scheduling of tests and discussion of test results. The team is led by a student project leader with a faculty member as advisor. At this point, initial tests have been conducted on a lab model for purposes of proving that the concept does produce electrical power by verifying literature results and getting team members acclimated to the science and design requirements of the concept. Current activity involves determining a prototype design for practical application where two concepts have been specified for design, fabrication and lab testing to determine which will be most effective, whereby a final design will be chosen and scaled for higher power production. The overall purpose of the project is to determine the design criteria for a full-scale device that can be made to work in a runoff-water catch-basin or sewage-treatment plant. The eventual objective is to build, install and monitor the performance of a fuel cell in an actual basin and possibly a sewagetreatment facility.

\section{The Basic Chemistry \& Biology}

The basic concept of a bacterial fuel cell is illustrated in Fig. 1, from Ref. 1. The overall process is summarized as follows:

1. Bacteria on the anode decompose organic matter and free $\mathrm{H}+$ ions and electrons.

2. Electrons flow from the bacteria to the anode, sometimes assisted by a mediator molecule.

3. Electrons flow up from the anode through a wire to the cathode generating electrical current.

4. The H+ ions flow through a semi-permeable membrane to the cathode.

This process is driven by the electro-chemical gradient resulting from a high concentration of $\mathrm{H}+$ ions near the anode.

5. Electrons from the cathode combine with dissolved oxygen and the $\mathrm{H}+$ ions to form pure $\mathrm{H}_{2} \mathrm{O}$. 
A critical component of the cell is the anode where the bacteria conglomerates and digests organic material to produce the necessary free electrons and hydrogen ions as illustrated in the following diagram:

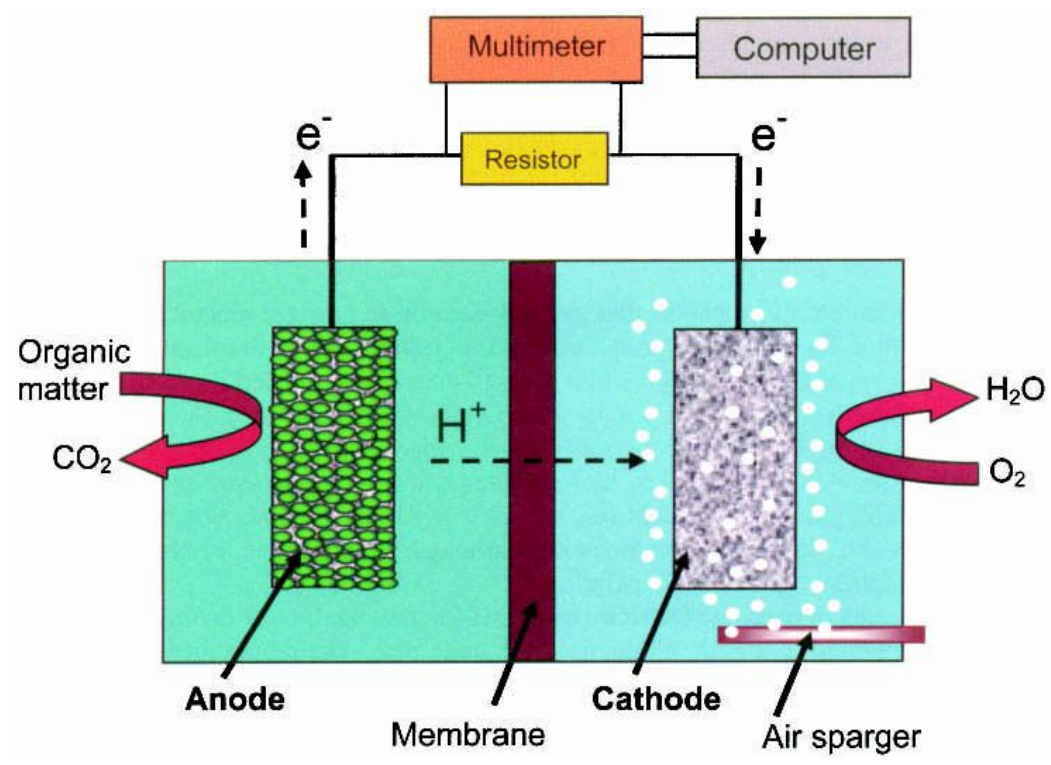

Fig. 1: Basic microbial or bacterial fuel cell.

The details of the microbiology in the anode chamber for an anaerobic process are:

- A solution containing organic material, consisting of glucose or acetate compounds commonly found in food waste and sewage, is circulated.

- The bacteria metabolize the material by first breaking apart the molecules into hydrogen ions, carbon dioxide $\left(\mathrm{CO}_{2}\right)$, and electrons.

- As shown in the following figure, bacteria use the electrons to produce energy by way of the electron-transport chain.

- The electron-transport chain is disrupted by a mediator molecule that shuttles electrons to the anode.

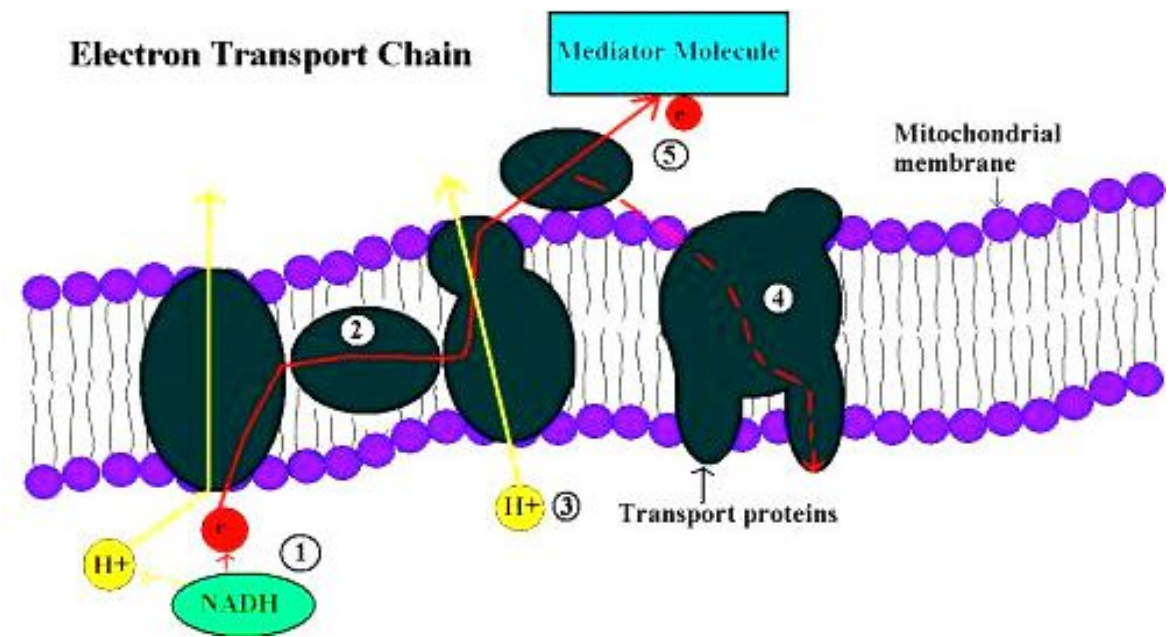

Mercer/Campbell and Reece/Pearson Education, Inc. 
The electron-transfer process is:

- The electron transport chain begins with NADH, a biological transport molecule that releases a high-energy electron $\left(\mathrm{e}^{-}\right)$and a proton $(\mathrm{H}+)$.

- The electron follows the red path through the proteins (large blobs) in the mitochondrial membrane.

- As an electron passes through each protein, it pumps hydrogen ions $(\mathrm{H}+)$ through the membrane.

- The electron continues along the red path, where it is acquired by a mediator molecule and transferred to the anode.

Note: In a simple bacterial cell, the electron traverses the dashed red path combining with oxygen to make water.

\section{Apparatus}

A laboratory unit shown in the following figure was tested. It is constructed of 6-inch diameter PVC pipe about 12-inches in length with a carbon-cloth anode and cathode and a Nafion protonexchange membrane. In this design, the cathode (end with black conductor) is exposed to open air and sits against the Nafion membrane that is exposed to the bacterial solution. The anode (white conductor) is immersed in the solution along the inner diameter of the PVC pipe. For the tests, $E$. coli bacteria was incubated in a 2 liter solution of lauryl tryptose broth and poured into the cell. Voltage and current was then recorded at various time intervals and bacterial concentration determined at beginning and end of the test period.

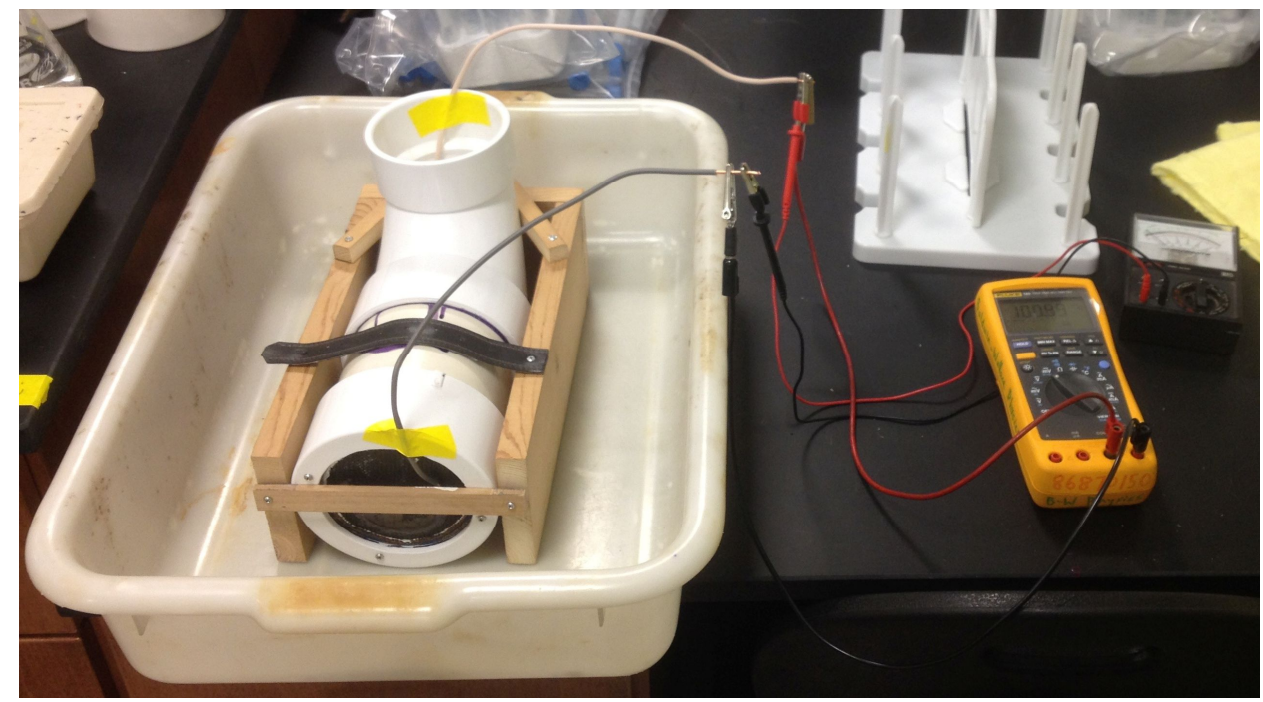

Fig. 2: Test apparatus.

\section{Test Results}

Voltage and current were measured in two sets of tests. The first test of the first set was done to check the device where the cell was run for 17 minutes with voltage manually recorded as given in Table 1 on the following page. The device produced open-circuit voltage of about $100 \mathrm{mV}$. In the second test of the first set, the cell was run for a period of 210 minutes with bacterial concentrations measured at beginning and end of the test period. Table 2 lists the open-circuit voltage and short-circuit current recorded over the test period, and Table 3 lists the analysis results for bacterial concentrations at beginning and end of the test period. At the end of the test period, a voltage of $98 \mathrm{mV}$ and current of $26 \mu \mathrm{A}$ were recorded with a bacterial concentration of 
$5.0 \times 10^{7} \mathrm{cfu} / \mathrm{ml}$ measured. The bacterial concentration about doubled over the test period accounting for the slight increase in open-circuit voltage over the same period.

In the second test set, the cell was run for 720 minutes with open-circuit voltage recorded and tabulated by use of a NiDaq (National Instruments Data Acquisition) unit on a laptop programmed in Python. The tabulated results are plotted in Fig. 3. The open circuit voltage was on the order of about $300-400 \mathrm{mV}$ over the test period. Initial bacterial concentration was $6 \times 10^{9}$ $\mathrm{cfu} / \mathrm{ml}$, considerably higher than in the first set of tests, accounting for the higher level of opencircuit voltage.

Table 1: Voltage for initial test, $1^{\text {st }}$ set:

\begin{tabular}{|c|c|}
\hline \multicolumn{2}{|c|}{ MFC Test 1 } \\
\hline $\begin{array}{c}\text { Time } \\
\text { (Mins) }\end{array}$ & $\begin{array}{c}\text { Voltage } \\
(\mathrm{mV})\end{array}$ \\
\hline 0 & 94.28 \\
\hline 4 & 96 \\
\hline 8 & 100.7 \\
\hline 10 & 101 \\
\hline 12 & 102 \\
\hline 14 & 103 \\
\hline 16 & 104 \\
\hline 17 & 105 \\
\hline
\end{tabular}

Table 2: Voltage \& current, 2nd test, $1^{\text {st }}$ set:

\begin{tabular}{|c|c|c|}
\hline \multicolumn{3}{|c|}{ MFC Test 2 } \\
\hline $\begin{array}{c}\text { Time } \\
(\text { mins })\end{array}$ & $\begin{array}{c}\text { ooltage } \\
(\mathrm{mV})\end{array}$ & $\begin{array}{c}\text { Amperage } \\
(\mu \mathrm{A})\end{array}$ \\
\hline 0 & 90 & 26 \\
\hline 15 & 63.6 & 16 \\
\hline 30 & 26.6 & 7.5 \\
\hline 210 & 98 & 26 \\
\hline
\end{tabular}

Table 3: Bacterial concentrations, 2nd test, $1^{\text {st }}$ set:

\begin{tabular}{|c|c|}
\hline \multicolumn{2}{|c|}{ MFC Test 2 } \\
\hline Time & $\begin{array}{c}\text { Concentration } \\
\text { (cfu/ml) }\end{array}$ \\
\hline Start & $2.4 \times 10^{\wedge} 7$ \\
\hline Finish & $5.0 \times 10^{\wedge} 7$ \\
\hline
\end{tabular}




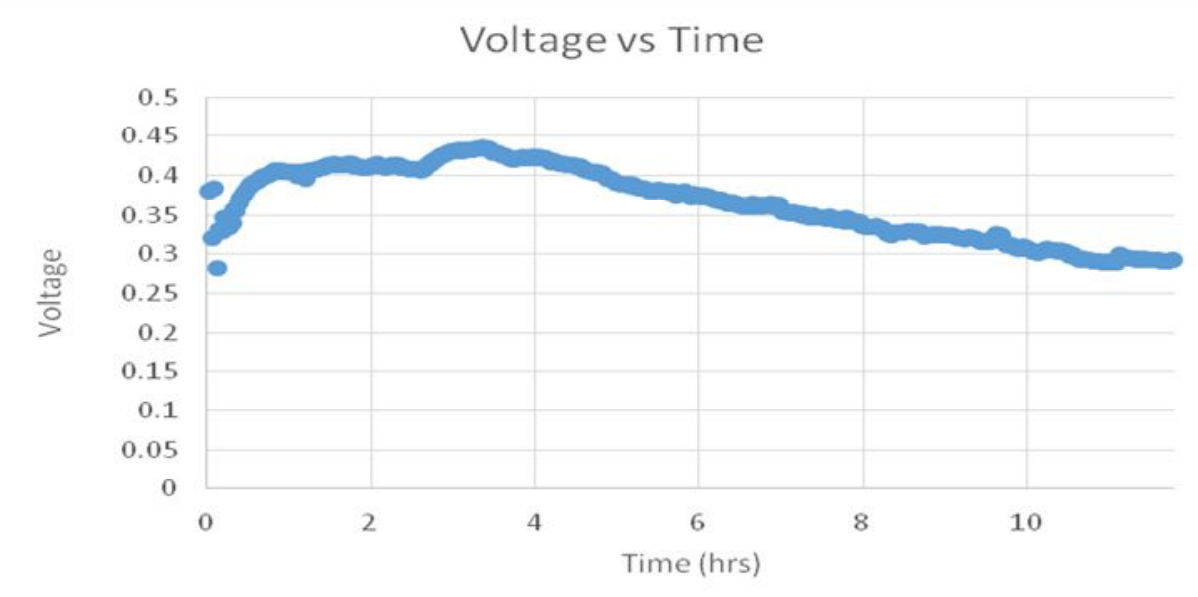

Fig. 3: Voltage, $2^{\text {nd }}$ test set.

\section{Conclusion}

From a pedagogical aspect, this project demonstrates the need for integrating the pertinent disciplines necessary to carry out a practical engineering project. It makes evident the requirement for planning, scheduling and performing the work of design, fabrication, testing, data acquisition and reporting results. It furthermore emphasizes the need for proper lab procedures in safe handling of bacteria, test apparatus and following proper procedures for disposal of bacterialcontaminated equipment.

Further tests are planned for the current school year with the goal of increasing power output by constructing more cells and connecting them in series and parallel to boost current and voltage to more practical, workable levels. Two designs are being considered, one utilizing graphite brushes and a second utilizing carbon fiber tubes. In both cases, the intent is to provide as much graphite area in a given volume as possible for the bacteria to conglomerate and grow. Testing other strains of bacteria is also planned, as is testing a larger unit in a still pond with naturally-occurring bacteria for purposes of verifying a practical design concept.

The students on this project are currently not receiving academic credit for their time and effort though the intent is to provide academic credit as independent study for next school year.

Furthermore, if grant funding is obtained, one or more students could receive compensation for their effort.

\section{Acknowledgement}

We would like to acknowledge other members of the project team: Mason Muldoon, Austin Conn, Jarrod Gilliam, Joseph Brisky, Austen Peppo. We would also like to acknowledge Prof. James McCargar, Chemistry Department, for his support and advice.

\section{References:}

1. Logan, Bruce E., Microbial Fuel Cells, John Wiley \& Sons, 2008.

2. Logan, Bruce. Microbial Fuel Cells: Q\&A. Penn State College of Engineering. Web.

3. Liu, Hong and Bruce Logan. Electricity Generation Using an Air-Cathode Single Chamber Fuel Cell in the Presence and Absence of a Proton Exchange Membrane. Department of Civil and Environmental Engineering and The Penn State Hydrogen Energy (H2E) Center. Web. 